\title{
TEACHING AND TRAINING
}

\section{using dating as an analogy to teach IR theory}

christopher I. pallas * and charity butcher

Kennesaw State University, 1000 Chastain Rd, MD 1602, Kennesaw, GA, 30144, USA.

${ }^{*}$ Corresponding author.

doi:10.1057/eps.2015.111; published online 26 February 2016

\begin{abstract}
Active learning techniques tend to emphasize simulations, research projects, and the use of popular media to the relative neglect of problem-based approaches. This paper introduces a new problem-based exercise specifically for teaching international relations (IR) theories that builds on existing problem-based approaches by incorporating analogies and an exemplarbased approach to concept learning. Teaching complex IR theories to students, who are often early in their academic careers, can be a challenge for many academic staff. Our approach uses a carefully structured analogy, based on a dating scenario, to challenge students to explain and theorize the behaviour of the key actors in a way that is transferable to an IR analysis of state behaviour. The exercise yields an intuitive understanding of core theories that facilitates subsequent learning and application.
\end{abstract}

Keywords international relations theory; active learning; concept learning; problem-based learning; analogies

A $S$ international relations (IR) academics, we have often encountered the difficulty students have in fully understanding various theories of IR. While students may be able to grasp the primary tenets of these theories, they frequently struggle to develop a deeper understanding that would allow them to apply these theories to explain real-world problems. To address this challenge, this paper sets out the case for an active learning exercise that utilizes the concept of dating and in so doing helps students understand the various tenets of IR theories, how these theories relate to one another, and how one might utilize these theories to explain a specific situation. Specifically, our exercise combines the use of analogies as a concept learning tool with problem-based learning (PBL) to assist students in understanding the function and application of IR theories.

The utility of active learning in the college classroom has been discussed by 
many scholars, including those in political science and international affairs. For example, The New International Studies Classroom: Active Teaching, Active Learning edited by Lantis et al (2000) provides many chapters dedicated to active learning (and teaching) in IR. More recently, Ishiyama et al (2015) edited the Handbook on Teaching and Learning in Political Science and International Relations, which includes many chapters about teaching using active learning techniques.

Scholars utilize active learning in IR in a variety ways, including the incorporation of classroom discussions, simulations, role-playing exercises, and films into the course. For example, many scholars have written on how incorporating simulations, role-playing exercises, or games into IR courses can help students learn and apply various concepts and theories (see, e.g., Dougherty, 2003; Shaw, 2004; Asal, 2005; Enterline and Jepsen, 2009; Simpson and Kaussler, 2009; Butcher, 2012; Bridge and Radford, 2014; Hatipoglu et al, 2014; Kempston and Thomas, 2014; Jones and Bursens, 2015). Powner and Allendoerfer (2008) found that both instructor-led discussions and role-playing exercises improve student performance on exams, compared with lectures alone. Other scholars have discussed how using film and television in the IR classroom can facilitate improved learning outcomes by encouraging critical thinking and the application of course concepts to these materials (see, e.g., Gregg, 1999; Lindley, 2001; Weber, 2001; Engert and Spencer, 2009; Simpson and Kaussler, 2009; Holland, 2015).

While there has been a plethora of studies focused on active learning exercises, such as simulations, some scholars have noted that much of the literature on active learning in the classroom focuses on only a few types of active learning activities. In particular, Ishiyama (2013) considers 176 articles from three US-based journals that publish on pedagogy and finds that the largest proportion of these articles focused on the use of simulation: 74 of 176 , or 42 per cent (Ishiyama, 2013: 119). Service learning and undergraduate research projects were also more commonly discussed than other types of active learning activities, such as PBL. Ishiyama suggests that $P B L$, which is an instructional method where students work together to solve problems, has some advantages over more frequently used simulations. PBL is associated with greater retention of information and material, promotes collaboration among students, and pushes students to solve real-world problems (Ishiyama, 2013: 123).

In this paper, we contribute to the growing literature on active learning by presenting an exercise that is different from those most usually discussed within much of the pedagogical literature. Our exercise, while having similar objectives to active learning techniques such as simulations, diverges from these other activities by incorporating elements of PBL and the use of analogy. An analogy, as we use it here, refers to a comparison between two things that have a similar structure (however defined) (see Duit, 1991 for a similar definition). While there is limited discussion of how to use analogies for teaching political science, cognitive psychologists often see analogies as a way to improve reasoning and there has been a greater attempt to implement the use of analogies and metaphors in learning in the hard sciences (Duit, 1991; Dagher, 1995; Coll et al, 2005). We also note that many political science professors employ various analogies when teaching concepts to our students, with this being because of an intuitive sense of their utility.

How exactly do analogies aid in learning? Analogies can help 'make the unfamiliar familiar' (Duit, 1991: 651). As such, analogies provide a link between what students already know to what they know less about. Thus, analogies aid in processing information - they allow students to understand a new concept or situation by 
seeing how it relates to (or is analogous to) a more familiar situation. This is the purpose of the exercise we describe below - to help students better understand IR theories by considering how these theories relate to another situation (dating) that they are more likely to be familiar with. In the particular case of IR theory, analogies can facilitate concept learning - that is, the learning of new categories or classifications of ideas (such as 'Marxist' or 'Realist') - by providing exemplars that can facilitate the sorting of new information (c.f. Rouder and Ratcliff, 2006). In other words, rather than asking of a given analysis only, 'Does this exhibit all of the characteristics of Realism?' a student can also ask, 'Does this analysis look similar to another, known Realist analysis I have already performed?' In this context, using something with which the student is familiar, such as dating, to build this exemplar facilitates initial comprehension.

Our specific analogy also builds upon the teaching strategy of $\mathrm{PBL}$, which is a student-centered approach to learning. Some of the key characteristics of PBL are that learning is often driven by practical problems, which may be openended and ill-defined; students work collaboratively in groups; and the professor takes on a facilitator role in the learning process (Ishiyama, 2013: 122). One of the main ideas behind PBL is that students learn more about a subject when they are engaged in deeper learning that is focused on solving a problem (Burch, 2000). In our exercise, students construct knowledge for themselves rather than having knowledge passively transferred to them; this is an important element of PBL (Maurer, 2015). Within this exercise, we utilize a PBL method along with an analogy to help students better understand IR theory. This is a novel pedagogical approach, and one that contributes to the literature of active learning-teaching strategies that move beyond simulations.
'...[A]nalogies provide a link between what students already know to what they know less about'.

\section{'...[A]nalogies aid in processing information - they allow students to understand a new concept or situation by seeing how it relates to (or is analogous) to a more familiar situation'.}

\section{DATING AND IR THEORY}

The analogy we use is something that many college students are familiar with, either directly or indirectly, namely dating and relationships. ${ }^{1}$ The overall exercise operates in the following way. First, students are invited to speculate on why a fictional couple, Matt and Mindy, ended their relationship. This is closely in line with the idea of solving practical problems, which is embedded in PBL. In a manner that is consistent with the collaboration portion of $\mathrm{PBL}$, the students work in small groups throughout the exercises that are focused on solving the puzzle as to why the relationship ended. To begin with, they suggest various causes for the breakup and these group answers are then written on a white board in unlabeled categories corresponding to four IR theories: realism, liberalism, neo-Marxism, and constructivism. Thereafter, the small groups are challenged to defend some of their answers. In the absence of any additional data from the instructor, students often defend their answers by postulating ideas about human nature or social 
interaction. These ideas are added to the appropriate columns. Finally, the instructor labels each of the four categories with an IR theory and links the students' ideas about human nature with the assumptions of each theory. During the exercise, the instructor acts as a facilitator, thereby allowing the students to take control of the exercise, which in itself is consistent with PBL. The students' experiences in the exercise become the basis for a follow-on discussion on the origins and use of theory. We discuss the specific elements of the exercise in greater detail below.

We have found this exercise to be particularly useful as a one-off introduction to IR theory for students with limited previous knowledge of political theory. For the most part we have tended to use this exercise in our Introduction to IR course in the second class of the term. For most of our students, this will only be the second politics or government class that they have taken at university, and the first with a substantial theory component. Thus, while the students engaged in this exercise will have read a textbook chapter on the history of IR and the nature of theory, they nonetheless have little understanding about specific theories. And while our students are typically in their second year or starting their third year of university study, we are nevertheless of the opinion that the intuitive nature of the exercise makes it appropriate for first-year students. ${ }^{2}$

Research on concept learning suggests that the understanding of new categories (e.g., realism or constructivism) requires both learning rules for what defines the category and exemplars of items within the category (Rouder and Ratcliff, 2006). While typical IR teaching stresses the rules for each theory, we believe that the use of an analogy helps create and strengthen category learning by providing initial exemplars. Thus, this exercise, by touching on the four main theories used in the course, as well as the concept of theory more generally, and relating them by analogy to a better-known phenomenon, helps create these conceptual categories and prepares students for subsequent learning.

At the same time, the shifting of the conversation away from a discussion about states or international institutions can help hone students' focus and clarify the discussion. Early in the semester, as they begin learning IR, students are confronted with a wide variety of new concepts - statehood, war, international organization, and so on. Using dating as a context for discussion of IR theory eliminates the potential distraction of other new concepts (and the potential confusion caused by incomplete comprehension) while highlighting that the IR theories being discussed are primarily defined by the interstate dynamics they predict and the theories of human nature upon which those predictions rest. Through this approach students are able to retain more information because they are actively engaged in solving a problem and creating knowledge for themselves rather than passively accepting information. In this way, the exercise promotes student learning and retention in both its use of an analogy and by employing some PBL techniques, of which we set out the various steps of the exercise below.

\section{STEP 1: THE PROMPT (10 MIN)}

We begin the exercise by warning students that it may seem like a digression from IR:

Today we'll be discussing the origins and use of theory in international relations. But to get there, we're going to be talking about something that may seem a little unusual for an IR course: dating. I ask that you bear with me; the logic will all be clear by the end of class.

We then divide the class into small groups of three to five students and ask 
each small group to consider the following scenario:

Picture yourself: you're having lunch with a friend [at a university eatery] and you notice that your friend looks kind of down. Being the good friend that you are, you ask what's wrong. Your friend replies, 'Do you know Matt and Mindy? I thought that they were the perfect couple. It gave me hope for my own romantic life. But today I found out that they broke up. And the worst part is, I don't even know why'.

Now you, being the good friend that you are, try to help out by offering some suggestions for why they broke up. So in your small groups, please come up with a list of at least 5 reasons why Matt and Mindy might have ended their relationship.

At this point, it is important to lay out some ground rules, both to protect students and to keep the exercise on track. First, students should be advised that this is a fictional scenario - and that they should keep it that way. References to specific events from their own dating experiences should be avoided and any references to their friends should be anonymous. Note that working in small groups may help protect students, since any statements made to the whole class are made on behalf of the group, rather than an individual.

Second, the exercise is speculative. Students do not have any data on Matt and Mindy and may not make any up. Thus, small group answers may include, 'Maybe Matt was cheating' but may not include 'I saw Matt with another girl'. We tell students, 'You don't actually have any information. You have only met Matt and Mindy once or twice. But you're going to offer your opinion anyway, because, if we're honest, sometimes that's what friends do, right?'

With these provisos, students are left to work in small groups for $5 \mathrm{~min}$. The instructor may circulate among the groups briefly to make sure that the discussions are on track, but we generally find that this is one small group exercise in which instructor coaching is largely unnecessary.

\section{STEP 2: EXPLAINING THE BREAKUP (20 MIN)}

After $5 \mathrm{~min}$, the instructor reconvenes the all-class discussion. Depending on the number of small groups, each group is invited to share one or two of their answers. Each answer is written on the board. The instructor continues calling on small groups (possibly returning to some groups for a second round of answers) until the class has given a complete range of answers, as will be described below, or answers become repetitive.

Answers are written on a white board in four unlabeled categories. These categories correspond to four core IR theories: realism, liberalism, neo-Marxism, and constructivism. Since IR, clearly, is not dating, the correspondence is established by focusing on the assumptions each theory holds about the core drivers of human (and state) behaviour. Realism emphasizes self-interested, short-term thinking, and a need to protect oneself from others' self-interested behaviour. Realism portrays individuals and states as power seeking, antagonistic, and distrustful and focuses on the importance of relative gains (where one gains more than others) rather than absolute gains (where one gains, even if others may gain more). Liberalism acknowledges self-interest, but finds that self-interest is best served through cooperation and integration into a community of like-minded actors. Liberalism also emphasizes absolute gains and considers that cooperation can lead to a 'win' for all sides. Marxism looks to economic motives, especially those that demonstrate the exploitation of one group by another. Constructivism focuses on beliefs, identities, and social norms as drivers of behaviour and sees ideas, language, 
Table 1: State of the Board at the end of Step 2 (example)

\begin{tabular}{|c|c|c|c|}
\hline Realism & Liberalism & Marxism & Constructivism \\
\hline S/he cheated & $\begin{array}{l}\text { He needed more } \\
\text { time with his } \\
\text { friends }\end{array}$ & $\begin{array}{l}\text { She made more } \\
\text { money than him } \\
\text { (which created a } \\
\text { power disparity) }\end{array}$ & $\begin{array}{l}\text { Decided was not } \\
\text { right for people of } \\
\text { different faiths to } \\
\text { date }\end{array}$ \\
\hline $\begin{array}{l}\text { Not physically } \\
\text { attracted any more }\end{array}$ & $\begin{array}{l}\text { Her family } \\
\text { disapproved } \\
\text { (and family } \\
\text { comes first) }\end{array}$ & $\begin{array}{l}\text { They had different } \\
\text { career goals }\end{array}$ & $\begin{array}{l}\text { Could not reconcile } \\
\text { their political beliefs }\end{array}$ \\
\hline He hit her & $\begin{array}{l}\text { They could not } \\
\text { communicate } \\
\text { well }\end{array}$ & $\begin{array}{l}\text { She borrowed too } \\
\text { much money from } \\
\text { him }\end{array}$ & $\begin{array}{l}\text { She did drugs and } \\
\text { he thought drugs } \\
\text { were bad }\end{array}$ \\
\hline $\begin{array}{l}\text { Discovered s/he } \\
\text { had a criminal } \\
\text { record }\end{array}$ & $\begin{array}{l}\text { He was jealous } \\
\text { when she spent } \\
\text { time with friends }\end{array}$ & $\begin{array}{l}\text { Her family was rich } \\
\text { and he was not } \\
\text { comfortable with } \\
\text { that }\end{array}$ & Cultural differences \\
\hline
\end{tabular}

and culture as important elements of power.

Many student responses fit readily into one of these categories. An answer like 'Matt was cheating' points to realist-style self-interest. 'Matt's family has money and Mindy's family is poor' would be placed under Marxism. Answers that begin with 'S/he didn't think it was right for ...' may reflect constructivist-style influence of norms or values. Liberalism can be a bit more difficult within this exercise, since liberalism is primarily concerned with cooperation and peace; its explanations for a conflict may overlap with realism. We suggest that instructors place answers in the categories that seem to fit best, recognizing they may need to clarify certain answers during the final stage to ensure that these are consistent with the specific theory. For example, an instructor might group in the liberalism column answers that reflect prioritizing adherence to a group or respect for community cohesion over individual interest, even though these answers may not completely fit within the category. During the final stage of the exercise, the instructor will need to take care to closely explain which parts of the answer typify the theory. An example of an answer that might fit in the liberal category might be 'Mindy's family didn't like Matt (and family was more important to her)'. Some typical answers for each category are given in Table 1.

Some answers may require some probing in order to establish where to place them. Here, the tutor's role as facilitator is very important. For instance, if a group were to offer that the couple broke up because 'Matt did drugs', the instructor must respond, 'why was that a problem for Mindy?' A response 'because Mindy felt like he was dangerous when he was high' would be placed in a realist column, while 'Mindy thought drugs were bad' would reflect a constructivist response.

A statement like 'Mindy made more money than Matt' might be placed under Marxism, realism, or constructivism, depending on the reasons why students believe this was an issue. If Matt is upset because making less money than Mindy makes him feel inferior to her, this might be placed under realism (as an example of relative gain). It could also be placed under constructivism, as the idea that not making 
as much as Mindy makes him inferior may be considered as a socially constructed norm. If Mindy's excessive earnings incline her to take a more dominant position toward Matt, or if she controls the money by not allowing Matt an equal say in how it is spent, this may be related to the exploitation and dominance present in more Marxist theories. If, after probing students, the response could still be placed in multiple categories, we suggest that the instructor place the item where it will be most useful for future discussion. So, if a response could be placed under realism or constructivism, but there are already a plethora of responses indicating that particular concept in realism, then the instructor could place the item under constructivism, or vice versa.

Student answers may be outlandish (Matt was a terrorist) or ribald, so it is important to use good classroom-management skills and maintain a non-judgmental demeanor. Instructor responses like 'Well, I suppose some people might feel that way' or 'Okay, that's one possibility. Let's get it on the board' are useful. Tolerating a moderate amount of cross talk between students can also help the class self-police. For instance, Matt is usually quickly accused of cheating - but often another student will interject 'Why do people always assume it's the guy who cheats?' The instructor can then reclaim the floor, 'Okay, so it could have gone either way', and then write on the board the gender neutral 'S/he cheated'.

\section{STEP 2B: EXPLAINING THE COUPLE'S RECONCILIATION (15 MIN - OPTIONAL)}

Scholars of IR will note that, for the reasons articulated above, liberal responses to the first portion of this exercise may be weak or require additional explanation. Thus we have begun to experiment with an extension of the exercise that would allow a greater discussion of liberal thought. If the instructor is so inclined, and feels that liberalism is not fully represented within the first portion of this exercise, then we would encourage them to consider adding this optional extension.

The instructor would begin this step with the following prompt to students:

A week later, you arrive for lunch with your friend and he is very excited. He tells you that Matt and Mindy have got back together! Your friend confides that he still doesn't know why they broke up - or why they decided to get back together, but he is happy to see that all has ended well. Now, since you had such fun speculating as to the reason for the breakup, you immediately begin to think of the potential reasons why the couple decided to reunite. So, in your groups, come up with 2-4 reasons why the couple may have reconciled.

Given that you are now asking students to explain a situation that is more cooperative in nature, you are likely to get additional responses that may fit into the category of liberalism. For example, students might say that 'Mindy and Matt decided they were better together'. Other responses might include that the two 'talked it out and came up with a solution' or that that 'they realised they still loved one another and could learn from their mistakes'. Each of these examples exhibits additional tenets of liberalism that may be difficult to demonstrate in the first portion of the exercise.

This optional extension to the exercise may also draw out additional explanations for the other theories of IR. Students might say that 'Matt was afraid of being alone', which suggests self-interest and fearfulness consistent with realism. Or, they might say, 'Matt needed Mindy's money to be able to sustain his lifestyle', which would be consistent with Marxist explanations. Table 2 shows how these additional explanations might be incorporated onto the classroom board. 
Table 2: State of the Board at the end of Step 2B (example)

\begin{tabular}{|c|c|c|c|}
\hline Realism & Liberalism & Marxism & Constructivism \\
\hline S/he cheated & $\begin{array}{l}\text { He needed more time } \\
\text { with his friends }\end{array}$ & $\begin{array}{l}\text { She made more money } \\
\text { than him (which } \\
\text { created a power } \\
\text { disparity) }\end{array}$ & $\begin{array}{l}\text { Decided was not } \\
\text { right for people of } \\
\text { different faiths to } \\
\text { date }\end{array}$ \\
\hline $\begin{array}{l}\text { Not physically } \\
\text { attracted any } \\
\text { more }\end{array}$ & $\begin{array}{l}\text { Her family disapproved } \\
\text { (and family comes } \\
\text { first) }\end{array}$ & $\begin{array}{l}\text { They had different } \\
\text { career goals }\end{array}$ & $\begin{array}{l}\text { Could not reconcile } \\
\text { their political beliefs }\end{array}$ \\
\hline He hit her & $\begin{array}{l}\text { They could not } \\
\text { communicate well }\end{array}$ & $\begin{array}{l}\text { She borrowed too } \\
\text { much money from him }\end{array}$ & $\begin{array}{l}\text { She did drugs and } \\
\text { he thought drugs } \\
\text { were bad }\end{array}$ \\
\hline $\begin{array}{l}\text { Discovered s/he } \\
\text { had a criminal } \\
\text { record }\end{array}$ & $\begin{array}{l}\text { He was jealous when } \\
\text { she spent time with } \\
\text { friends }\end{array}$ & $\begin{array}{l}\text { Her family was rich and } \\
\text { he was not } \\
\text { comfortable with that }\end{array}$ & Cultural differences \\
\hline \multirow[t]{3}{*}{$\begin{array}{l}\text { S/he was afraid } \\
\text { of being alone }\end{array}$} & $\begin{array}{l}\text { They were better } \\
\text { together }\end{array}$ & $\begin{array}{l}\text { One needed the other } \\
\text { to sustain lifestyle }\end{array}$ & $\begin{array}{l}\text { They realised they } \\
\text { had a lot in common }\end{array}$ \\
\hline & $\begin{array}{l}\text { Still loved and trusted } \\
\text { each other }\end{array}$ & $\begin{array}{l}\text { One could not live } \\
\text { without the other }\end{array}$ & \\
\hline & $\begin{array}{l}\text { Talked it out and came } \\
\text { up with a solution }\end{array}$ & & \\
\hline
\end{tabular}

\section{STEP 3: DATING AND HUMAN NATURE (20 MIN)}

As answers go up on the board, students become curious about what the columns represent. The fact that answers are being ordered signals to students that this is a meaningful exercise and their curiosity keeps them engaged. At this point, we tell the students:

You can see that this is leading somewhere; the answers are obviously in groups. But before I tell you what they mean, I want us to take this one step further. Let's say that you give your friend your explanation and they push back. You say, 'I bet Matt and Mindy broke up because Matt cheated'. And your friend says, 'No, I don't think that could be it'.
You want to double-down on your answer. You think cheating could really be the explanation, and you want to persuade your friend. How are you going to do it? Remember, you still don't have any data - there's no evidence Matt was cheating. So how are you going to make your argument that cheating was the cause?

I want you to think about this in your small groups. Pick two answers from the board, from two different columns, and come up with an argument you would use to persuade your friend.

We then give the students an additional 5-8 min in small groups. If students are firmly forbidden from creating ad hoc evidence, they tend to engage in intuitive theory-building, basing their answers on broad observations about 
human nature, society, or history. This is part of the PBL technique that we mentioned previously. It is useful to circulate among the small groups coaching them toward this outcome by affirming student ideas that are headed in the right direction and reminding students of the ground rules. After 5-8 min, the all-class discussion is reconvened and the instructor again collects answers from the small groups and writes them, in abbreviated form, under the list of causes. Table 3 provides some explanations of typical student answers.

\section{STEP 4: THE REVEAL}

We now reveal to students the labels of the columns and the importance of the exercise for the class:

You are already, in a way, doing IR theory. The four columns on the board correspond to four core IR theories. [Label columns with the headings indicated in brackets in Tables 1, 2, and 3.] Each of these theories makes different assumptions about human nature and the dynamics that govern human interaction.

This link then leads us to a brief discussion of each theory and the assumptions and predictions they make, connecting them where possible with the ideas the students have put forward. We are also careful to emphasize that this discussion is just an overview and that a detailed study of each would be covered in the weeks ahead. Professors can also indicate those responses that might correspond to different theories if the explanation is varied. This helps students better see how the theories relate to one another. The entire exercise allows students to see how theories might be applied to explain specific situations - in the particular example here, a conflict.

Discussing the theories, in turn, leads us to an interactive lecture on what theory
'If students are firmly forbidden from creating ad hoc evidence, they tend to engage in intuitive theory-building, basing their answers on broad observations about human nature, society, or history'.

is and how theory is developed and used. The exercise provides a reference point as students see how they have used broad observation and their sense of 'historical' trends to create assumptions that allow them to explain other actors' behaviour. If you choose to include Step 2B, you can also illustrate how most IR theories are meant to be 'grand' theories that can explain all state behaviour, and that this can be demonstrated in how various theories can explain both conflict and cooperation. However, you can also use this opportunity to point out that some theories, because of their orientation, may do a better job of explaining one or the other (conflict or cooperation).

\section{ALTERNATIVE FRAMING OF THE EXERCISE: BEYOND DATING}

While we feel that dating/courtship is a topic that many college and university students are familiar with, we also recognize that concepts related to dating are culturally relative and may not resonate with all student bodies. However, with small adjustments, we believe that this activity can work in a variety of cultural contexts. While dating may not resonate with all students, we believe that most students can relate to the broader idea of interpersonal relationships. As such, we would recommend that instructors 


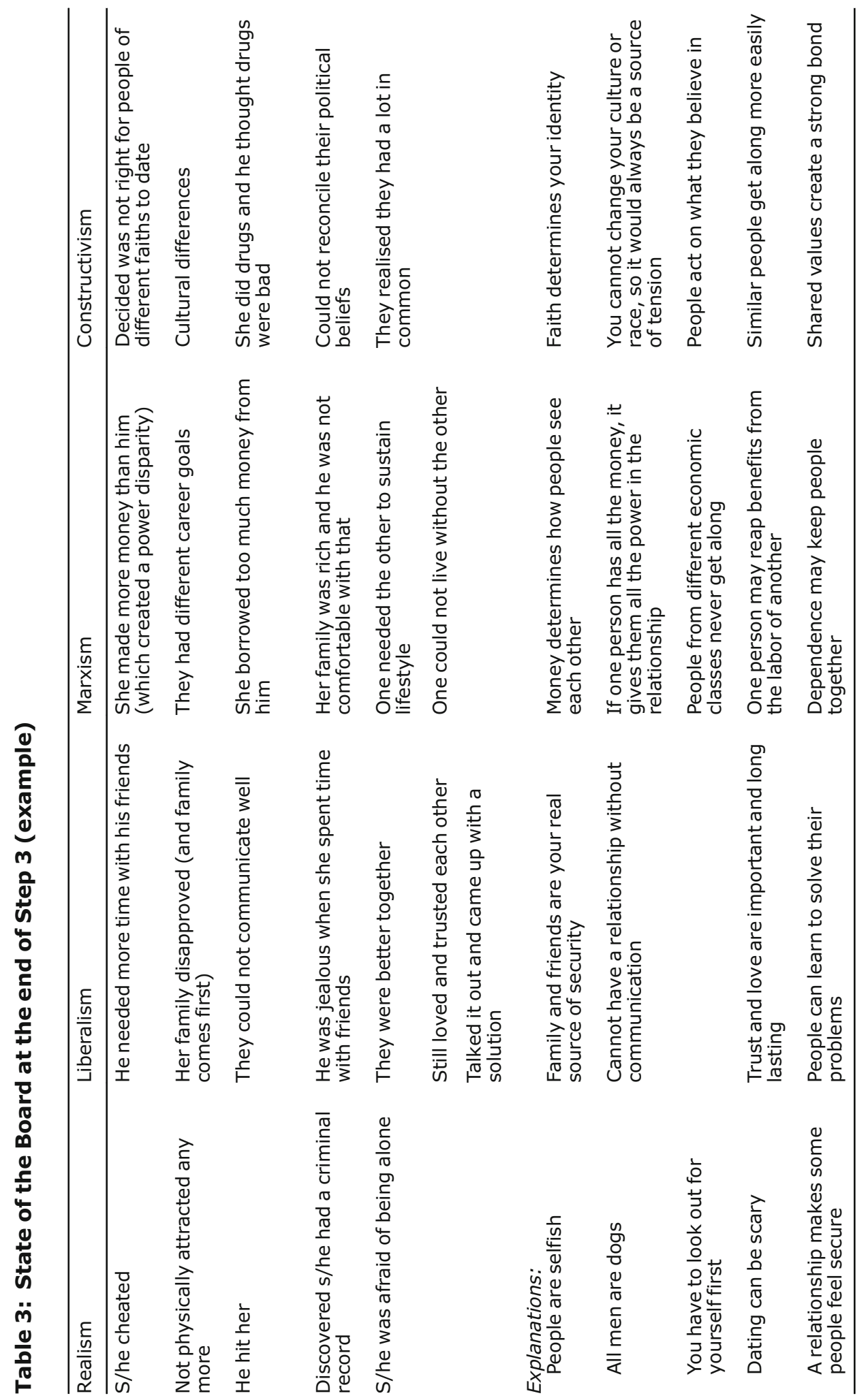

108 european political science: 162017 using dating as an analogy to teach IR theory 
consider the following alternative scenario (instead of the dating scenario presented above) if they feel that such would be more relatable for their students.

\section{ALTERNATIVE STEP 1: PROMPT}

Picture Yourself: You're having lunch with a friend at [a university eatery] and you notice that your friend looks kind of down. Being the good friend that you are, you ask what's wrong. Your friend replies, 'Do you know Gina and Jill? They have been friends since they were 5 years old and were practically inseparable! They were such a great model of a strong, long-lasting friendship. I just found out they are no longer friends - they are not even speaking to one another! And the worst part is, I don't even know why'.

Now you, being the good friend that you are, try to help out by offering some suggestions for why Gina and Jill might have ended their friendship. So in your small groups, please come up with a list of at least 5 reasons why Gina and Jill might have ended their friendship.

Instructors can vary the names of the individuals and/or the type of relationship (siblings, roommates, teammates, etc.) as they think appropriate for the context in which they are teaching. If using Step 2B, the instructor can simply adjust the prompt according to the scenario they use, perhaps stating that the two friends have reconciled. One of the strengths of this exercise is that we believe it can be adjusted appropriately to fit a variety of student contexts.

\section{IMPACT OF THE EXERCISE}

After using this exercise for eight semesters, we have found that it consistently produces a positive impact on students. Students have evaluated their learning
'... TT]he intuitive snapshot gained through the analogy facilitates theory application in a way that the memorization of theory details would not'.

experiences in each of these classes using standardised university surveys and consistently reported a high degree of satisfaction with the course and the problem-based style in which it is taught. While the survey data does not highlight the specific role of this one exercise, anecdotal data from conversations with students indicates the effectiveness of the exercise. In line with the predictions in the PBL literature, the exercise is highly memorable. Our university runs on 15-week terms and students have referenced lessons from this exercise as much as 12 weeks after the exercise. Moreover, our impression is that many students continue to use an exemplar-based approach to category learning when understanding IR theories. In conversations with the instructor, students will frequently refer back to this exercise as a way of framing a question they have about how a given theory works. This seems to be particularly true for average and below-average academic performers, who may struggle with some of the more sophisticated readings and have greater difficulty in mastering the nuances of each theory. For these students, the intuitive snapshot gained through the analogy facilitates theory application in a way that the memorization of theory details would not. Significantly, students' essay results (over the course of eight written assignments each term) show a general comprehension of the dynamics of each theory across all students in the class, including those students whose essays reveal (via a lack of citations or nuanced discussion) limited comprehension or assimilation of the details of each theory. 


\section{CONCLUSION}

We have found that this 'dating' analogy is a good way to introduce new IR theories to students and a useful expansion on existing approaches to interactive learning. By employing an analogy to associate something new (IR theory) with something familiar (dating), the exercise facilitates student comprehension of the new material. Moreover, it provides students with an initial set of exemplars for how different IR theories explain conflict (and potentially cooperation), complementing the rulebased approach to concept learning typically employed in teaching IR theory. The exercise is also flexible, so that instructors can change the relational context (to include friendship, family, etc.) if more appropriate for the institutional or cultural context in which they are teaching.

The exercise has proved to be particularly helpful in introducing theory to students who are relatively new to the study of government or political science. Classroom results indicate that the method is effective and memorable. While useful for all students as an introductory exercise, the exercise has a particular benefit for average and belowaverage performers, for whom an exemplar-based approach to theory learning may yield an intuitive ability to apply theory and significant retention of core concepts. It also provides an interesting and engaging means of introducing stu-
'...[The exercise] provides students with an initial set of exemplars for how different IR theories explain conflict (and potentially cooperation), complementing the rulebased approach to concept learning typically employed in teaching IR theory'.

dents to active learning early in the term, preparing them for future PBL techniques.

One of the key strengths of this exercise is that academics can tailor it to their own specific needs. As such they can decide how they would like to categorize student responses, as some responses might fit in multiple categories. Additional IR theories can also be included if the lecturer is inclined to do so, while at the same time it is possible to exclude some of the theories that we have discussed. For example, while we have not explicitly considered feminist approaches to IR, lecturers may wish to include a separate column for feminist IR theory. The flexibility of this exercise allows it to be utilized by lecturers in a way that fits with the objectives of the individual course.

\section{Notes}

1 We recognize that while dating - that is, forming publicly acknowledged, yet informal romantic attachments - is common in many cultures, it is not universal. If dating is not a concept with which you feel your students can relate, an alternative scenario focusing on friendship is presented at the end of the discussion of the exercise.

2 Actual ages of the students involved have ranged from a teenage high-school student enrolled in university courses to several non-traditional students in their thirties, forties, and older. All participated with enthusiasm. 


\section{References}

Asal, V. (2005) 'Playing games with international relations', International Studies Perspectives 6(3): 359-373.

Bridge, D. and Radford, S. (2014) 'Teaching diplomacy by other means: Using an outside-of-class simulation to teach international relations theory', International Studies Perspectives 15(4): 423-437.

Burch, K. (2000) 'A primer on problem-based learning for international relations', International Studies Perspectives 1(1): 33-44.

Butcher, C. (2012) 'Teaching foreign policy decision-making processes using role-playing simulations: The case of US-Iranian relations', International Studies Perspectives 13(2): 176-194.

Coll, R., France, B.K. and Taylor, I. (2005) 'The role of models/and analogies in science education: Implications from research', International Journal of Science Education 27(2): 183-198.

Dagher, Z.R. (1995) 'Review of studies on the effectiveness of instructional analogies in science education', Science Education 79(3): 295-312.

Dougherty, B. (2003) 'Byzantine politics: Using simulations to make sense of the Middle East', PS: Political Science and Politics 36(2): 239-244.

Duit, R. (1991) 'On the role of analogies and metaphors in learning science', Science Education 75(6): 649-672.

Engert, S. and Spencer, A. (2009) 'International relations at the movies: Teaching and learning about international politics through film', Perspectives: Central European Review of International Affairs 17(1): 83-103.

Enterline, A.J. and Jepsen, E. (2009) 'Chinazambia and Boliviafranca: A simulation of domestic politics and foreign policy', International Studies Perspectives 10(1): 49-59.

Gregg, R.W. (1999) 'The ten best films about international relations', World Policy Journal 16(2): 129-134.

Hatipoglu, E., Muftuler-Bac, M. and Murphy, T. (2014) 'Simulation games in teaching international relations: Insights from a multi-day, multi-stage, multi-issue simulation on cyprus', International Studies Perspectives 15(4): 394-406.

Holland, J. (2015) 'Visual Literacy in International Relations: Teaching Critical Evaluative Skills through Fictional Television', International Studies Perspectives advance online publication 6 February, doi:10.1111/insp.12098.

Ishiyama, J. (2013) 'Frequently used active learning techniques and their impact: A critical review of existing journal literature in the United States', European Political Science 12(1): 116-126.

Ishiyama, J., Miller, W. and Simon, E. (eds.) (2015) Handbook on Teaching and Learning in Political Science and International Relations, Cheltenham, UK: Edward Elgar Publishing.

Jones, R. and Bursens, P. (2015) 'The effects of active learning environments: How simulations trigger affective learning', European Political Science 14(3): 254-265.

Kempston, T. and Thomas, N. (2014) 'The drama of international relations: A South China sea simulation', International Studies Perspectives 15(4): 459-476.

Lantis, J., Kuzma, L. and Boehrer, J. (eds.) (2000) The New International Studies Classroom: Active Teaching, Active Learning, Boulder, CO: Lynne Rienner.

Lindley, D. (2001) 'What I learned since I stopped worrying and studied movies: A teaching guide to Stanley Kubrick's 'Dr. Strangelove", PS: Political Science and Politics 34(3): 663-667.

Maurer, H. (2015) 'Best Practices in Problem-Based Learning', in J. Ishiyama, W. Miller and E. Simon (eds.) Handbook on Teaching and Learning in Political Science and International Relations, Cheltenham, UK: Edward Elgar Publishing, pp. 35-46.

Powner, L.C. and Allendoerfer, M. (2008) 'Evaluating hypotheses about active learning', International Studies Perspectives 9(1): 75-89.

Rouder, J. and Ratcliff, R. (2006) 'Comparing exemplar-and rule-based theories of categorization', Current Directions in Psychological Science 15(1): 9-13.

Shaw, C.M. (2004) 'Using role-playing scenarios in the IR classroom: An examination of exercises on peacekeeping operations and foreign policy decision making', International Studies Perspectives 5(1): $1-22$.

Simpson, A.W. and Kaussler, B. (2009) 'IR teaching reloaded: Using films and simulations in the teaching of international relations', International Studies Perspectives 10(4): 413-427.

Weber, C. (2001) 'The highs and lows of teaching IR theory: Using popular films for theoretical critique', International Studies Perspective 2(3): 281-287. 


\section{About the Authors}

Christopher L. Pallas is Assistant Professor of Conflict Management at Kennesaw State University. He holds a Ph.D. in Social Policy from the London School of Economics. His research focuses on transnational civil society, global governance, and the democratization of international policymaking. He is the author of Transnational Civil Society and the World Bank: Investigating Civil Society's Potential to Democratize Global Governance (2013, Palgrave Macmillan) and has published articles in Review of International Organizations, Global Governance, Development Policy Review, Voluntas, and other journals. He also holds a UK Postgraduate Certificate in Higher Education. He regularly teaches introductory courses in international relations and mentors doctoral students in their teaching.

Charity Butcher is an Associate Professor of Political Science and International Affairs at Kennesaw State University, where she also teaches in the Ph.D. in International Conflict Management program. She received her Ph.D. in political science from Indiana University. Her research focuses on terrorism and civil wars; democratization; civil society and NGOs; and the importance of ethnicity and religion in international conflict and rivalry. In addition, she conducts research on the Scholarship of Teaching and Learning (SoTL), focusing on the use of simulations and other in-class activities, as well as multi-media, within the classroom. Her work has been published in a variety of journals, including International Studies Perspectives, Terrorism and Political Violence, Democratization, and PS: Political Science and Politics. 